\title{
Preparation of Wills in Times of COVID-19 PANDEMIC - SELECTED OBSERVATIONS
}

\begin{abstract}
Pandemic time is a situation of increased human deaths, which cannot be left without the influence and interest of the law of succession. Some legislators have prepared and enacted appropriate facilities for the use of formal instruments for disposing of property upon death specifically for the pandemic period. The author looks at these solutions and wonders whether it is appropriate to deformalize the law of succession for the period after the pandemic, while presenting the statutory solutions of selected states.
\end{abstract}

KEYWORDS: will, testament, testamentary formalities, pandemic, succession law

\section{Problem Setting - Introduction}

The interest in the law of succession is increasing from time to time. In Poland, we have experienced this when the market economy has emerged after the communist era because the values of estates have increased and inheritance dispute problems have begun (Stelmachowski 1998). At that time the succession law was experiencing its revival. But I think that the same has happened in the world in recent years, due to the dynamic development of new technologies and their impact on succession law. There was a heated discussion, legislators have changed the law, the doctrine have criticized the change, and the courts have done what they usually do, they have settled disputes against these changes (Zimmermann 2016). So succession law was 
developing (Cottier 2014). However, a pandemic of unexpected proportions caused social isolation and made it difficult to use the mechanisms of succession law (Horton and Weisbord 2020). This is a paradox, since at the same time the pandemic period is a period of increased mortality and therefore a period of greater interest in the law of succession than usual.

These are not just intuitive statements. For example, in England, Coronavirus has prompted a 76\% jump in the demand for wills (Slingo 2020) - at least according to the data provided by the on-line succession service provider - deVere Group (deVere Group 2020). In Australia, the demand for wills soared by 300\% in March 2020 (Newbould 2020).In the Republic of South Africa, between January and March 2020, there has been a 660\% increase in enquiries for wills, compared to the same period of the previous year (Thomson 2020). Similar data are also available from other countries. So it seems that the law of succession is becoming "alive" again, the pandemic is an impulse for its practical applications. But is it really possible to make a will during a pandemic? Have the legal provisions in force in this respect foreseen such a situation? Was the law in need of change? Were such changes introduced? These are some questions that seem justified even today, as the pandemic continues to develop and the desire to make an act of last will appears to an increasing number of people. In this article I am trying to search for the answers.

\section{RESEARCH OBJECTIVE}

The aim of the article is to present selected aspects of the issue of making wills in a pandemic, including the search for answers to the question of how to make a valid will. Selected legal systems, which have presented solutions for drawing up wills in the COVID-19 pandemic will be analyzed. Since some legislators have prepared and enacted appropriate facilities for the use of formal instruments for disposing of property upon death specifically for the pandemic period, the author looks at these solutions and wonders whether it is appropriate to deformalize the law of succession for the period after the pandemic. Because of that, a path for the legislator's future is be proposed, in the light of current trends in the world of testamentary formalities. 


\section{RESEARCH METHODS}

The analysis of legal solutions will be based on the dogmatic method, which will be supported by comparative considerations. The article refers to selected legal instruments of some countries, including New Zealand, Australia and Canada, indicating the solutions adopted by their legislators during the pandemic. A few comments will also be made on social expectations. The issues of succession law require looking not only at the laws of one country, but also at the current trends in order to take into account the current expectations of society. The presentation focuses on those countries that have changed their legislation in this area as a result of the pandemic.

\section{TESTAMENT AS A FORMAL LEGAL ACT AND A PANDEMic. SubJect MATter of THE WORK}

Before I will try to answer the aforementioned questions, I believe that some repetition of succession law is needed first. As it is known, a testament (or last will - as it is called in English) is a formal legal act (Sitkoff and Dukeminier 2017). The obligation to keep a form for the act of a last will is nowadays a rule applicable in all democratic legal systems in the world (Kerridge, Brierley, and Parry 2016). Only a will created in accordance with the framework set by the legislator for this legal act can cause the legal effects desired by the testator. Contradiction in creating a last will with the provisions of the law therefore generally means its invalidity (Röthel 2014).

The regulations on the form of wills have evolved over the years since old Roman times. Nowadays, it is mainly French, German and Austrian legislation, as well as the English regulation, that has had a significant impact on the shape of legal acts of succession in other countries (Reid, Dewall, and Zimmermann 2011). Despite a number of differences characterising specific statutory solutions, the most common forms of wills are holographic wills, witnessed wills and public wills, where the testator's last will is declared in the presence of an official (Załucki 2019). Does a pandemic change anything in drawing up a will?

Firstly, in many countries the practice of making wills is based on the legal advice of an experienced lawyer (Zimmermann 2012). Secondly, the statutory requirements very often require the participation of other people in 
the drafting of wills (Aloy 2016). There are laws where a testator is required to be in one room with witnesses in order to make a last will. The same applies to official persons who must attend certain forms of wills. It follows that quite often the condition for drawing up a will is to be present around other people (Reid, Dewall, and Zimmermann 2011). Even when the law does not provide for this, we often seek specialist advice, without which we do not decide to draw up a will. The pandemic changes these habits drastically, as does the possibility of meeting the requirements of the presence of different people in one place and time. Existing bans on gathering, bans on approaching, bans on moving around - all of this significantly limits the possibility of making a will (Horton and Weisbord 2020). The pandemic therefore affects the possibility of making a will. In many countries, a will without the participation of others may prove to be void despite a pandemic. As it seems, an important question to be answered is how to draw it up to be valid?

\section{A VALID WILL}

The question about preparing a will in the age of pandemic may have some answers. The easiest and most obvious one is certainly the one according to which it is necessary to make a will that does not require the presence of other persons, such as a holographic will. However, not all legal systems provide for such a possibility, moreover, in common law countries, such a possibility is rare (Sitkoff and Dukeminier 2017). Rather, the rule is the obligation to make a will in the presence of other persons (Kerridge 2000). A will is not valid unless it is witnessed correctly or signed correctly (for example by a notary). In this respect, during a pandemic, statutory changes loosening the formal requirements for preparation of such wills were necessary.

According to the above, the second answer could be: to make statutory changes. This option seemed to be necessary in some countries. For example in New Zealand, the government has made a law change to modify the requirements for signing and witnessing wills under the New Zealand's Wills Act of 2007. Epidemic Preparedness (Wills Act 2007-Signing and Witnessing of Wills) Immediate Modification Order 2020 introduced the principle that during the pandemic wills could have been signed and witnessed using audiovisual links. The change allowed wills to be done by Zoom, Skype, Facetime, Google Meet etc. The same has happened, for example, in Australia. 
For example in Queensland, as of 15 May 2020, according to COVID-19 Emergency Response Act 2020, video conferencing technology was admitted to be used for having important end of life legal documents witnessed. Also, some Canadian provinces have taken some steps to allow individuals to witness a will through videoconferencing technology. The changes have also affected notarial wills. According to the new Quebec's pandemic regulation (Order 2020-010 of the Minister of Health and Social Services), as of 1 April 2020, notarial wills were admitted to be signed remotely. The reacting legislator can therefore be a solution for those who want to prepare a will during pandemic. But this is not the case of every legislator. For example, in Poland, none of the above has happened. The preparation of a will during the pandemic is exactly the same as it used to be before the pandemic. In the case of an allographic or notarial will, the law in force during a pandemic requires the participation of other persons in the act of last will (Załucki 2015). This is similar in many other European countries Are civil rights distorted? Some might think so since notarial or official testaments are not possible or very difficult to be prepared due to the social isolation obligation. In this respect, the third answer to the posted question arises: to ask legislator for statutory changes.

Such changes to the succession law seems necessary. The changes would allow the testator's declaration of intent to be fulfilled at the time when there is a real risk of his death. So wherever it is possible, the legislator should follow the already existing patterns and admit remote signing or witnessing a will. The legislator can also follow some old-known patterns, like solutions based on the doctrine of "substantial compliance" and its variations (Langbein 1975). Especially the latter solutions seem tempting. The model of succession based on the doctrine of substantial compliance and its variations takes into account a number of untypical behaviours of the testator, including those that may occur during a pandemic.

It is important to recall here that some jurisdictions will admit a document into probate if it is in substantial compliance with the wills act formalities. To satisfy the substantial compliance standard: 1 . there must be clear and convincing evidence that the testator intended the document to be his last will and testament, and 2. the will substantially complies with the wills act formalities (Menashe 2007)which, provided that certain basic conditions are met, enables the validation of flawed wills. The Article 
presents the position taken by the Supreme Court, according to which Section 25 requires that prior to its validation, the authenticity of a will be proven beyond any doubt. This standard is criticized as impracticable and normatively flawed, as is another standard, suggested by some Supreme Court Justices, which would impose on those wishing to validate a flawed will a standard of proof similar to that required in criminal law. The Article then attempts to create a desirable model for the probative standard found in Section 25. This model is based on disutility equations for decision-making under conditions of uncertainty; it leads to the conclusion that the standard that should be required in order that flawed wills be validated is considerably lower than that demanded by today s case law. The Article claims that there is no significant risk that testators might be led to disregard or neglect the formal requirements set by the Succession Law for writing wills. In conclusion, some arguments are presented in support of a revolutionary hypothesis: I suggest that the Supreme Court's interpretation of Section 25 reflects an ideology that prefers the mode of asset distribution prescribed by inheritance law over alternative modes, created by individual wills. The Court's preference, however, is not grounded (and cannot reasonably be grounded. A similar doctrine, called the "harmless error" doctrine, gives the courts even more leeway to change a will by only requiring that the testator intended the document to be his last will. It does not require the document to be in substantial compliance with the wills act formalities. This is also called the "dispensing power" because it allows the courts to dispense with the strict wills act formalities as long as there is clear and convincing evidence for the remedy (Uzcategui 2015). Whereas previous departures focused on whether the document in question was in "substantial compliance" with will formalities, the harmless error doctrine focuses on the decedent's intent. For example, California's Probate Code Section 6110(c) (2), provides as follows: "If the will was not executed in compliance with paragraph (1) the will shall be treated as if it was executed in compliance with that paragraph if the proponent of the will establishes by clear and convincing evidence that, at the time the testator signed the will, the testator intended the will to constitute the testator's will". It seems that there is no turning back from this kind of trend in the law of succession. Similar solutions are found primarily in Anglo-American countries, including many US state legislations, Canada, Australia and South Africa (Crawford 
2019). The same pattern can be found in Israel, among others (Flaks 2010). A pandemic is, it seems, a time when it is necessary and will be necessary to resort to such mechanisms to reflect the will of the testator. These solutions will also, as one might think, make it possible to keep in force those wills which will be drawn up during pandemic without complying with all formal requirements. There is a social need for such solutions.

It is during a pandemic that when drawing up a will, the testator will often act in fear of imminent death, disregarding the formalities. The lack of a signature, the lack of witnesses, computer print-outs instead of writing, video recordings instead of the relevant protocol, the lack of an attestation clause - these are just some of the flaws that may come to light when drawing up wills. Authorities applying the law should bear this in mind and strive to keep the testator's last will in force. The mechanisms introduced by the law can certainly facilitate this. The absence of such mechanisms in specific legislation should not, however, immediately determine the invalidity of the will. In the law of succession, the principle of a generous interpretation of favor testamenti applies. Based on this principle and on mechanisms known from the doctrine of substantial compliance, it is possible to consider that a given disposition of property upon death fulfils its statutory role (Załucki 2019). All that is needed for this is willingness.

\section{TEMPORARY CHANGES OR NEW ERA OF TESTAMENTARY FORMALITIES}

Thinking about the changes made in some legislation due to the pandemic, it has to be recalled that the changes are temporary. In majority of circumstances, the modifications will expire (or has already expired) after the pandemic notice is lifted. The law will return (or has already returned) to its previous wording. But is it and was it necessary? Shouldn't the changes remain in force? Since less formality is and was required from the testator during the pandemic, couldn't that also be the case after the pandemic?

I strongly believe that loosening of formal requirements in the law of succession is what the society needs. Whether we are in Australia, New Zealand, Canada or Poland, the law should follow the spirit of the times, allowing wills to be made in a way that is separate from the Guttenberg era (Dubravka Klasiček 2019). In the world of technology it is difficult to comply 
with old school formal requirements. In the course of the pandemic, some legislators have noticed this. It's time for a bigger scale.

The introduction of solutions facilitating the drafting of a will seems to be a trend in modern legal systems. The law of succession, which dates back largely to Roman times, needs to be aired. A new, fresh outlook seems to accentuate the need to modernise it. In this case, modernity will be achieved by means of instruments which make it easier for society to use the mechanisms of disposing of property in case of death. The whole range of solutions found in many countries around the world is increasingly subordinated to this thought. Only solutions that allow for a real reflection of the Testator's wishes are expected. Any changes measuring in this direction should be considered desirable. Therefore, the facilitations that were introduced during the pandemic should be firmly anchored in everyday legislation. Remote signing, remote witness participation, videoconferencing - these are today's standards for modern legal transactions. It cannot be expected that succession law should continue to be analogue, since we live and die in digital times. It is time to start noticing it on a daily basis.

The temporary changes, which referred to increased social expectations (a significant increase in interest in drawing up wills in some countries), are already thought to have the desired effect. Testators will draw up valid wills, on the basis of which the heirs will benefit from the succession. The law of succession will be given new instruments or there will be a reinterpretation of existing positions. Paradoxically, therefore, a pandemic, despite its generally negative effects, may become and is slowly becoming a stimulus for legal changes. The events before the pandemic in no way gave such a strong impulse for change. Despite the general feeling of the need for such changes, a pandemic may turn out to be the beginning of a new era of testamentary formalities.

\section{Conclusions}

It is appropriate to deformalize the law of succession for the period after the pandemic. The solutions adopted during the pandemic have shown that it is possible for testators to take greater account of their interests. In succession law such solutions were and still are expected. The changes aimed at facilitating the drafting of wills, reducing the weight of formalities, will allow for greater reflection of the testator's will. This seems to be the desired 
direction. A modern legislator, caring about the interest of testators and the proper functioning of social relations, should bear this in mind. It is possible that we are witnessing a new era of testamentary formalities. This era will hopefully be an era of taking into account the will of the testator at the expense of formal requirements, of truly reflecting the needs of society, of using legal instruments in accordance with their proper purpose. There should be no turning back from this.

\section{Bibliography}

Aloy, A. V. (2016). "La Relajación de Las Solemnidades Del Testamento". Revista de Derecho Civil 3 (4): 9-34. ISSN 2341-2216.

Cottier, M. (2014). "Adapting Inheritance Law to Changing Social Realities: Questions of Methodology from a Comparative Perspective." Oñati Socio-Legal Series 4 (2): 196-221. ISSN 2079-5971.

Crawford, B. J. (2019). "Wills Formalities in the Twenty-First Century." Wisconsin Law Review, no. 2: 269-94. ISSN 0043-650X.

deVere Group. (2020). “Report: Demand for Wills up 76\%: Coronavirus 'Collectively Focuses Minds.” https:/www.devere-group.com/news/Demand-for-wills-up76-percent-Coronavirus-collectively-focuses-minds.aspx.(access 1.07.2020).

Dubravka Klasiček. 2019. “21 St Century Wills.” Pravni Vjesnik 35 (2): 29-48. ISSN 0352-5317.

Flaks, S. (2010). "Excusing Harmless Error in Will Execution: The Israeli Experience."

Estate Planning and Community Property Law Journal 3 (3): 27-54. ISSN 21612463.

Horton, D., and Reid Kress W., (2020). "COVID-19 and Formal Wills." Stanford Law Review Online, 1-11. ISSN 0038-9765.

Kerridge, R. (2000). Hawkins on the Construction of Wills. London : Sweet \& Maxwell Ltd. ISBN 9780421609006.

Kerridge, R., Alastair B., and Hughes Parry D., (2016). Parry and Kerridge: The Law of Succession. 13th ed. London: Sweet \& Maxwell. ISBN 9780409347722.

Langbein, J. H. (1975). "Substantial Compliance with the Wills Act." Harvard Law Review 88 (3): 489-531. https://doi.org/10.2307/1340322.

Menashe, D. (2007). "Relaxed Formalism: The Validation of Flawed Wills." Israel Law Review 40 (1): 119-55. https://doi.org/10.1017/S0021223700013273. 
Newbould, J. (2020). "Demand for Wills on the Rise as Coronavirus Fears Set in for Australians." Money Magazine, no. 8 April 2020. ISSN 0149-4953.

Reid, K. G.C., M. J. Dewall, and R. Zimmermann, eds. (2011). Comparative Succession Law. Testamentary Formalities. Oxford: Oxford Scholarship. ISBN 9780199696802.

Röthel, A. (2014). “Testamentsformen.” Juristische Ausbildung 5 (5): 475-82. ISSN 0170-1452.

Sitkoff, R. H., and J. Dukeminier. (2017). Wills, Trusts, and Estates. 10th ed. New York: Wolters Kluwer. ISBN 9781454874287.

Slingo, J. (2020). "Coronavirus: Demand for Wills Jumps by 76\%." The Law Society Gazette, no. 31 March 2020. https://www.lawgazette.co.uk/news/coronavirusdemand-for-wills-jumps-by-76/5103703.article. (access 1.07.2020)

Stelmachowski, A. (1998). Zarys Teorii Prawa Cywilnego. Warszawa: Wydawnictwa Prawnicze PWN. ISBN 8387558036.

Thomson, A. (2020). “The Demand for Wills Is Increasing in SA as Covid-19 Spreads - and Divorces May Spike Too." Business Insider SA, no. 11 April 2020. https:// www.businessinsider.co.za/increase-in-wills-and-divorce-spikes-2020-4. (access 1.07.2020)

Uzcategui, J. (2015). "Application of the Harmless Error Doctrine in California and Beyond." California Trusts \& Estates Quarterly 21 (1): 1.

Załucki, M. (2015). Uniform European Inheritance Law. Myth, Dream or Reality of the Future. Kraków: AFM Publishing House. ISBN 9788365208026. https://doi. org/10.1017/CBO9781107415324.004.

- 2019. "About the Need to Adjust the Regulations Regarding the Form of Will to the Modern Requirements." The European Journal of Economics, Law and Politics 6 (2): 1-13. https://doi.org/10.19044/elp.v6no2a1.

Zimmermann, R. (2012). “Testamentsformen:»Willkür «oder Ausdruck Einer Rechtskultur?" Rabels Zeitschrift Für Ausländisches Und Internationales Privatrecht 76 (3): 471-508. https://doi.org/10.1628/003372512801786881.

- 2016. “Kulturelle Prägung Des Erbrechts?” Juristen Zeitung 71 (7): 321-32.

\section{Footnotes}

${ }^{1}$ Mariusz Załucki is a Full Professor of Law and the Head of the Institute of Private Law at AFM Krakow University (Poland), mzalucki@afm.edu.pl, ORCID: 00000002-3338-3832. The article is part of a research project funded by the National Science Centre (Poland), agreement No. UMO-2018/29/B/HS5/00361. 